\title{
SISTEM PENDUKUNG KEPUTUSAN PENERIMA PROGRAM BEASISWA PELANGI MENGGUNAKAN METODE ANALYTICAL HIERARCHY PROCESS
}

\author{
Nova Yolanda Nurrisma Hidayati ${ }^{1)}$, Tati Mardiana ${ }^{2)}$, Laela Kurniawati ${ }^{3)}$ \\ ${ }^{1,3}$ Sistem Informasi, STIMIK Nusa Mandiri \\ ${ }^{2}$ Teknologi Informasi, Universitas Bina Sarana Informatika \\ ${ }^{1}$ Jl. Damai No. 8, Warung Jati Barat (Margasatwa), Pasar Minggu, RT.1/RW.1, Ragunan, Pasar Minggu, Jakarta \\ 12540 \\ ${ }^{2}$ J1. Kramat Raya No. 98, RT.02/RW09,Kwitang, Kec. Senen, Jakarta Pusat 10450 \\ ${ }^{3}$ Jatiwaringin RT.08/RW.13 Cipinang Melayu, Kec.Makasar Jakarta Timur 13620 \\ Email:1'novayo11162336@nusamandiri.ac.id,2 tati.ttm@bsi.ac.id, ${ }^{3}$ laela@nusamandiri.ac.id
}

\begin{abstract}
Education is the most important role, especially in Indonesia. Scholarships can be said to be financial assistance provided by the government, companies, organizations and partnerships to someone who is less well off and / or achievers to help with education costs. To determine scholarship recipients in the rainbow scholarship program, INTI collection is able to provide scholarships on the right target for children who are carrying out their education. Because the selection process uses interviews with applicants and the interview process uses only 5 students in the comparison of student assessments during the interview, this study uses 5 applicant students as alternatives and has 4 criteria including: Parents' monthly income, student attitudes or personalities, average value of report cards and social care embedded in students. In the process of receiving scholarships using a decision support system with the application of the only method (AHP) using manual calculations with Microsoft Excel to produce priority weights and get the rating of each attribute and compare it with the system program created by the author showing priority weights, ranking and can print the results of the report.
\end{abstract}

Keyword: Scholarship, Analytical Hierarchy Process, Pelangi Scholarship

\begin{abstract}
Abstrak
Pendidikan merupakan peranan terpenting khususnya di Indonesia. beasiswa dapat dikatakan sebagai bantuan berupa keuangan yang diberikan oleh pemerintah, perusahaan, organisasi dan kemitraan kepada seseorang yang kurang mampu dan maupun berprestasi untuk membantu biaya pendidikan. Untuk menentukan Penerima beasiswa pada program beasiswa pelangi penghimpunan INTI untuk bisa memberikan beasiswa tepat sararan kepada anak yang sedang menjalankan pendidikannya. Karena proses penyeleksi menggunakan wawancara terhadap pemohon dan proses wawancara hanya menggunakan 5 siswa dalam perbandingan penilaian siswa saat wawancara maka penelitian ini menggunakan 5 siswa pemohon sebagai altenatif dan memiliki 4 kriteria diantaranya: Penghasilan orang tua perbulan, Sikap atau Kepribadian siswa, Nilai rata-rata raport dan Kepedulian sosial yang tertanam pada diri siswa. Dalam proses penerimaan beasiswa menggunakan sistem pendukung keputusan dengan penerapan metode satunya (AHP) menggunakan perhitungan manual dengan Microsoft Excel menghasilkan bobot prioritas dan mendapatkan perengkingan dari setiap atribut dan membandingkannya dengan program sistem yang dibuat oleh penulis menampilkan bobot prioritas, perengkingan dan dapat mencetak hasil laporan.
\end{abstract}

Kata Kunci: Beasiswa, Analytical Hierarchy Process, Beasiswa Pelangi.

\section{Pendahuluan}

Pendidikan memegang peranan penting dalam rangka mengurangi kesenjangan sosial dan angka kemiskinan, baik di Indonesia maupun Negara lain [1]. Berdasarkan data dari Badan Pusat Statistik, Angka Partisipasi Kasar (APK) jenjang sekolah menangah atas atau sederajat tahun 2019 secara umum mencapai 83,98 persen [2], dibandingkan dengan tahun 2018 mencapai 80,68 persen [3]. Tahun 2019 data angka putus sekolah pada menengah atas atau sederajat mencapai 1,76 persen [2]. Pendidikan sering mengalami permasalahan, faktor ekonomi keluarga yang tidak memadai menjadi permasalahan pada anak putus sekolah. Oleh karena itu, pemerintah, organisasi, yayasan atau perusahaan memberikan beasiswa untuk mengurangi jumlah anak putus sekolah dengan memberikan beasiswa berupa uang yang diberikan kepada anak-anak rentan putus sekolah yang berguna demi keberlangsungan pendidikan yang ditempuh [4]. Beasiswa merupakan pemberian bantuan 
keuangan untuk pendidikan yang ditempuh perorangan, mahasiswa atau pelajar bagi yang memiliki prestasi dalam bidang akademik, non akademik dan perekonomian lemah yang telah memenuhi syarat yang ditentukan oleh pihak pemberi beasiswa [5]. Lembaga pemberi beasiswa mengharapkan agar penerima beasiswa dapat membentuk generasi baru yang memiliki kecerdasan dan kepintaran yang lebih dengan alasan seseorang bisa memiliki kesempatan untuk mendapatkan pendidikan yang lebih tinggi [6].

Pengambilan keputusan yang memiliki beberapa kriteria menggunakan logika Fuzzy Multiple Attribute Decision Making (FMADM). Fuzzy Multiple Attribute Decision Making merupakan suatu metode bertujuan untuk mencari altenatif optimal dari beberapa altenatif dengan kriteria tertentu, FMADM digunakan untuk menentukan suatu nilai bobot untuk setiap atribut yang selanjutnya dilakukan perengkingan yang menyeleksi altenatif yang diberikan [7]. . Metode AHP melakukan pemecahan suatu masalah ke dalam bagian-bagian komponen dan menata bagian atau elemen kedalam suatu susunan hirarki. Proses hirarki analisis memiliki prinsip dasar untuk memecahkan persoalan menjadi unsur yang terpisah, yang harus dilakukan pertama menentukan permasalahan terkait kemudian menyusun model struktur secara hirarki yang terdiri dari tujuan utama, kriteria dan altenatif. Hirarki fungsional merupakan hal paling utama dengan input utamanya persepsi manusia, dengan hirarki suatu masalah yang kompleks dan tidak terstruktur yang dipecahkan kedalam kelompoknya dan diatur menjadi suatu hirarki [8].

Penghimpunan Indonesia Tionghoa (INTI) pada 2 Mei 2008 meluncurkan program beasiswa kepada anak-anak yang memiliki kepedulian sosial terhadap sesama, memiliki sikap yang baik dan yang kurang mampu dalam ekonomi tetapi keinginan kuat untuk bersekolah di daerah Jabodetabek dengan membiayai sumbangan pembinaan pendidikan maksimal Rp. 250.000 perbulan secara tunai dengan waktu pengambilan dana per 2 bulan. Jumlah pendaftar beasiswa semakin bertambah dan hanya pendaftar yang memenuhi kriteria yang akan menerima beasiswa. Keputusan untuk menentukan siapa yang berhak menerima beasiswa membutuhkan ketelitian dan waktu relative lama karena melibatkan banyak kriteria [9], oleh karena itu dibutuhkan sistem yang memberikan informasi sebagai dasar dalam pengambilan keputusan yang cepat dan baik. Untuk proses pengambilan sebuah keputusan yang mempunyai beberapa macam kriteria menggunakan logika Fuzzy Multiple Attribute Decision Making (FMADM). Macam-macam metode yang dikembangkan, pada Penerapan AHP untuk menentukan penerima beasiswa pada SMAN 9 Padang dengan permasalahan pada proses pemilihan tidak ada kriteria yang jelas, dari penelitian tersebut peneliti menganalisis menggunakan metode AHP dengan menghasilkan nilai CR -1,115 dari nilai CI -1,0035 dan RI 0,9 dari nilai CR tersebut sehingga matriks berpasangan untuk kriteria tidak konsisten. Penerapan FMADM juga dilakukan untuk metode TOPSIS pada SMAN 2 Tebing Tinggi Timur dengan menghitung dan menghasilkan nilai terbaik melalui hasil pembobotan dan pemeringkatan, dari perhitungan peneliti mendapatkan perengkingan pertama dengan nilai prefensi 0.75982 yang layak mendapatkan beasiswa. Peneliti juga mengusulkan web untuk penyeleksi beasiswa penerapan metode TOPSIS [10]. maka penulis memilih metode Analytical Hierarchy Process sebagai metode yang memiliki hasil yang lebih baik dalam seleksi penerimaan beasiswa sebagai metode yang digunakan untuk melakukan penelitian ini karena dalam metode AHP dapat memberikan hasil yang lebih konsisten dengan menggunakan perhitungan kuantitatif dan memiliki struktur berhirarki yang lebih mudah dipahami. Beasiswa pelangi mengambil Keputusan untuk menentukan siapa yang berhak menerima beasiswa belum menggunakan sistem keputusan yang tepat dan sesuai kriteria sehingga sering terjadinya ketidakpastian pemberian beasiswa. maka diperlukannya sistem pendukung keputusan dengan metode analytical Hierarchy Process yang membantu program beasiswa pelangi dalam melakukan penyeleksian.

\section{Bahan dan Metode}

Penelitian ini bertujuan untuk membangun sistem pendukung keputusan menentukan penerima beasiswa menggunakan metode AHP yang bertujuan untuk mempercepat proses dan menghasilkan nilai keputusan yang optimal. Pada penelitian ini penulis memilih jenis penelitian eksperimen. Tahapan penelitian ini dimulai dari melakukan identifikasi suatu masalah yang ada pada tempat penelitian. Masalah yang dapat diidentifikasikan adalah Program beasiswa pelangi untuk mengambil keputusan belum menggunakan sistem keputusan yang tepat, yang sesuai kriteria sehingga tidak tepatnya untuk menentukan penerima beasiswa dan belum adanya alat bantu untuk proses penyeleksian beasiswa sehingga mengakibatkan kesulitan dalam menentukan penerima beasiswa. Setelah melakukan tahapan identifikasi masalah, maka tahap selanjutnya pengumpulan data.

Data yang digunakan pada penelitian ini menggunakan data yang didapatkan secara langsung melalui proses pengamatan dan sumber yang bersangkutan secara langsung dan data yang didapatkan dari teori yang ada hubungannya dengan permasalahan yang diteliti. Penelitian ini menggunakan teknik untuk mengumpulkan data adalah studi pustaka, wawancara dengan tim penyeleksi beasiswa pelangi dan observasi. Berdasarkan pengumpulan data yang sudah terkumpul maka dilakukan analisis mengenai kriteria dan penerapan metode AHP dalam studi kasus untuk menentukan penerimaan beasiswa pada beasiswa pelangi

\section{Hasil dan Pembahasan}




\section{A. Metode Pengambilan Keputusan Menggunakan Metode AHP}

Kriteria untuk menentukan penerimaan beasiswa pada program beasiswa pelangi INTI yang disepakati dari tim penyeleksi beasiswa pelangi. Menggunakan lima altenatif antar lain: Ahmad (A) Keyza (K), Nazwa (N), Haikal (H) dan Daniar (D) dengan empat kriteria untuk menentukan penerimaan beasiswa, antara lain: penghasilan orang tua yang dikalkulasi pendapatan perbulan $(\mathrm{P})$, nilai rata-rata semester akhir $(\mathrm{N})$, sikap siswa (S) dan kepedulian sosial terhadapat lingkungan sekitar (K). Dari empat kriteria maka dibuatkan struktur hirarki. Berikut struktur hirarki kriteria penerimaan beasiswa yang dapat dilihat pada gambar 1 .

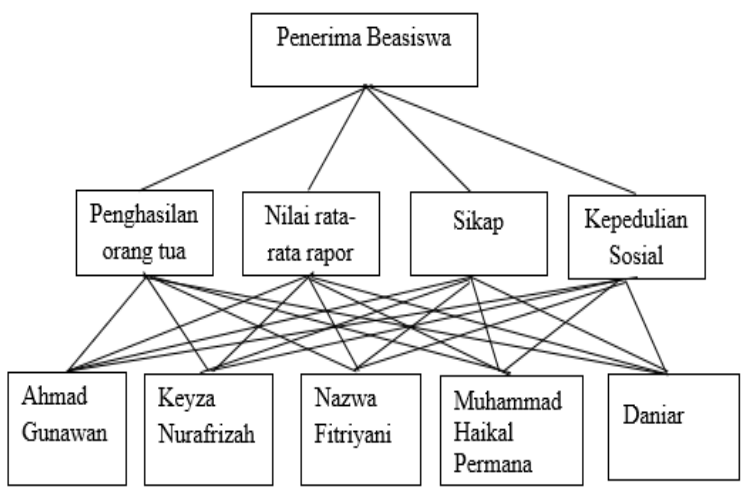

Gambar 1. Struktur Hirarki Untuk Menentukan Penerimaan Beasiswa

Perbandingan dilakukan berdasarkan penilaian lima orang tim penyeleksi dengan tingkat kepentingan satu elemen dengan elemen yang lain. Hasil dari matrik perbandingan berpasangan untuk memperoleh satu matrik harus dilakukan rata-rata ukur dengan Geometrik Mean (GM) yang dapat dilihat pada tabel dibawah ini.

Tabel 1. Geometrik Mean Kriteria Utama

\begin{tabular}{lllll}
\hline & $\mathbf{P}$ & $\mathbf{N}$ & $\mathbf{S}$ & $\mathbf{K}$ \\
\hline $\mathrm{P}$ & 1,0000 & 4,3734 & 0,2841 & 0,2091 \\
\hline $\mathrm{N}$ & 0,1657 & 1,0000 & 0,2841 & 0,2165 \\
\hline $\mathrm{S}$ & 3,5195 & 3,5195 & 1,0000 & 0,4884 \\
\hline $\mathrm{K}$ & 4,7818 & 4,6179 & 1,4841 & 1,0000 \\
\hline Total & $\mathbf{9 , 4 1 0}$ & $\mathbf{1 3 , 5 1 0 8}$ & $\mathbf{3 , 0 5 2 4}$ & $\mathbf{1 , 9 1 4 0}$ \\
\hline
\end{tabular}

Sumber : Hidayati, Mardiana, Kurniawati (2020)

Tabel 2. Geometrik Mean Kriteria Penghasilan

\begin{tabular}{llllll}
\hline & $\mathbf{A}$ & $\mathbf{K}$ & $\mathbf{N}$ & $\mathbf{H}$ & $\mathbf{D}$ \\
\hline $\mathrm{A}$ & 1,0000 & 2,1689 & 0,2187 & 0,2422 & 0,2016 \\
\hline $\mathrm{K}$ & 0,4611 & 1,0000 & 0,1955 & 0,3615 & 0,4251 \\
\hline $\mathrm{N}$ & 4,5731 & 5,1146 & 1,0000 & 4,5144 & 3,5652 \\
\hline $\mathrm{H}$ & 4,1289 & 2,7663 & 0,2215 & 1,0000 & 1,2457 \\
\hline $\mathrm{D}$ & 4,9593 & 2,3522 & 0,2746 & 0,8027 & 1,0000 \\
\hline Total & $\mathbf{1 5 , 1 2 2 4}$ & $\mathbf{1 3 , 4 0 2 0}$ & $\mathbf{1 , 9 1 0 3}$ & $\mathbf{6 , 9 2 0 8}$ & $\mathbf{6 , 4 3 7 7}$ \\
\hline
\end{tabular}

Tabel 3. Geometrik Mean Kriteria Nilai

\begin{tabular}{llllll}
\hline & $\mathbf{A}$ & $\mathbf{K}$ & $\mathbf{N}$ & $\mathbf{H}$ & $\mathbf{D}$ \\
\hline $\mathrm{A}$ & 1,0000 & 2,6052 & 0,2841 & 2,5508 & 2,4022 \\
\hline $\mathrm{K}$ & 0,3839 & 1,0000 & 0,1748 & 0,2947 & 0,2717 \\
\hline $\mathrm{N}$ & 3,5195 & 5,7203 & 1,0000 & 2,3522 & 2,8252 \\
\hline $\mathrm{H}$ & 0,3920 & 3,3935 & 0,4251 & 1,0000 & 0,3540 \\
\hline $\mathrm{D}$ & 0,4163 & 3,6801 & 0,2947 & 2,8252 & 1,0000 \\
\hline Total & $\mathbf{5 , 7 1 1 6}$ & $\mathbf{1 6 , 3 9 9 1}$ & $\mathbf{2 , 1 7 8 8}$ & $\mathbf{9 , 0 2 2 9}$ & $\mathbf{6 , 8 5 3 2}$ \\
\hline
\end{tabular}

Tabel 4. Geometrik Mean Kriteria Sikap

\begin{tabular}{llllll} 
& $\mathbf{A}$ & $\mathbf{K}$ & $\mathbf{N}$ & $\mathbf{H}$ & $\mathbf{D}$ \\
\hline $\mathrm{A}$ & 1,0000 & 1,3608 & 0,2025 & 1,1732 & 0,3264 \\
\hline $\mathrm{K}$ & 0,7348 & 1,0000 & 0,2100 & 0,8891 & 0,2264 \\
\hline $\mathrm{N}$ & 4,9393 & 4,7625 & 1,0000 & 1,8882 & 1,4310 \\
\hline $\mathrm{H}$ & 0,8524 & 1,1247 & 0,5296 & 1,0000 & 0,5065 \\
\hline $\mathrm{D}$ & 3,0639 & 4,4163 & 0,6988 & 1,9332 & 1,0000 \\
\hline Total & $\mathbf{1 0 , 5 9 0 5}$ & $\mathbf{1 2 , 6 6 4}$ & $\mathbf{2 , 6 4 0 9}$ & $\mathbf{6 , 8 8 3 6}$ & $\mathbf{3 , 4 9 0 3}$ \\
\hline
\end{tabular}

Tabel 5. Geometrik Mean Kriteria Kepedulian

\begin{tabular}{llllll}
\hline & $\mathbf{A}$ & $\mathbf{K}$ & $\mathbf{N}$ & $\mathbf{H}$ & $\mathbf{D}$ \\
\hline $\mathrm{A}$ & 1,0000 & 0,5641 & 0,4611 & 0,3147 & 0,3010 \\
\hline $\mathrm{K}$ & 1,7726 & 1,0000 & 0,2187 & 0,3010 & 0,3807 \\
\hline $\mathrm{N}$ & 2,1689 & 4,5731 & 1,0000 & 3,6801 & 1,2336 \\
\hline $\mathrm{H}$ & 3,1777 & 3,3227 & 0,2717 & 1,0000 & 0,5610 \\
\hline $\mathrm{D}$ & 3,3227 & 2,6265 & 0,8106 & 1,7826 & 1,0000 \\
\hline Total & $\mathbf{1 1 , 4 4 1 9}$ & $\mathbf{1 2 , 0 8 6 4}$ & $\mathbf{2 , 7 6 2 1}$ & $\mathbf{7 , 0 7 8 4}$ & $\mathbf{3 , 4 7 6 3}$ \\
\hline
\end{tabular}

Setelah mendapatkan nilai geometric mean langkah selanjutnya melakukan penilanan relative pada setiap sel dengan cara nilai setiap sel dibagi jumlah pada setiap kolomnya maka akan memperoleh nilai relative per sel. Selanjutnya setiap faktor secara horizontal dijumlahkan dan dicari bobot prioritas (ev) kriterianya. Perhitungan bobot prioritas di mulai dari perhitungan bobot prioritas kriteria utama dan bobot prioritas altenatif terkait dengan kriteria, hasil selengkapnya sebagai berikut:

1. Berdasarkan Kriteria Utama

Tabel 6. Bobot Prioritas Kriteria Utama Menentukan Eigenvector

\begin{tabular}{llllll}
\hline & $\mathbf{P}$ & $\mathbf{N}$ & $\mathbf{S}$ & $\mathbf{K}$ & $\boldsymbol{E v}$ \\
\hline $\mathrm{P}$ & 0,1056 & 0,3237 & 0,0931 & 0,1093 & 0,1579 \\
\hline $\mathrm{N}$ & 0,0175 & 0,0740 & 0,0931 & 0,1131 & 0,0744 \\
\hline $\mathrm{S}$ & 0,3718 & 0,2605 & 0,3276 & 0,2551 & 0,3038 \\
\hline $\mathrm{K}$ & 0,5051 & 0,3418 & 0,4862 & 0,5225 & 0,4639 \\
\hline Total & & & & & $\mathbf{1 , 0 0 0 0}$ \\
\hline
\end{tabular}

2. Berdasarkan Kriteria Penghasilan

Tabel 7. Bobot Prioritas Kriteria Penghasilan 


\begin{tabular}{lllllll} 
& \multicolumn{6}{c}{ Menentukan Eigenvector } \\
\hline \multirow{2}{*}{$\mathrm{A}$} & $\mathbf{A}$ & $\mathbf{K}$ & $\mathbf{N}$ & $\mathbf{H}$ & $\mathbf{D}$ & $\boldsymbol{E} \boldsymbol{v}$ \\
& 61 & 0,16 & 0,11 & 0,03 & 0,03 & \multirow{2}{*}{0,0817} \\
\multirow{2}{*}{$\mathrm{K}$} & 0,03 & 0,07 & 0,10 & 0,05 & 0,06 & \multirow{2}{*}{0,0651} \\
& 05 & 46 & 23 & 22 & 60 & \\
\hline \multirow{2}{*}{$\mathrm{N}$} & 0,30 & 0,38 & 0,52 & 0,65 & 0,55 & \multirow{2}{*}{0,4827} \\
& 24 & 16 & 35 & 23 & 38 & \\
\multirow{2}{*}{$\mathrm{H}$} & 0,27 & 0,20 & 0,11 & 0,14 & 0,19 & \multirow{2}{*}{0,1867} \\
& 30 & 64 & 60 & 45 & 35 & \\
\multirow{2}{*}{$\mathrm{D}$} & 0,32 & 0,17 & 0,14 & 0,11 & 0,15 & \multirow{2}{*}{0,1837} \\
& 79 & 55 & 38 & 60 & 53 & \\
\hline \multirow{2}{*}{ Total } & & & & & & 1,0000 \\
\hline
\end{tabular}

3. Berdasarkan Kriteria Nilai

Tabel 8. Bobot Prioritas Kriteria Nilai Menentukan Eigenvector

\begin{tabular}{lllllll} 
& $\mathbf{A}$ & $\mathbf{K}$ & $\mathbf{N}$ & $\mathbf{H}$ & $\mathbf{D}$ & $\boldsymbol{E} \boldsymbol{v}$ \\
\hline \multirow{2}{*}{$\mathrm{A}$} & 0,17 & 0,15 & 0,13 & 0,28 & 0,35 & \multirow{2}{*}{0,2195} \\
& 51 & 89 & 04 & 27 & 05 & \\
\multirow{2}{*}{$\mathrm{K}$} & 0,06 & 0,06 & 0,08 & 0,03 & 0,03 & \multirow{2}{*}{0,0561} \\
& 72 & 10 & 02 & 27 & 97 & \\
\hline \multirow{2}{*}{$\mathrm{N}$} & 0,61 & 0,34 & 0,45 & 0,26 & 0,41 & \multirow{2}{*}{0,4193} \\
\hline \multirow{2}{*}{$\mathrm{H}$} & 62 & 88 & 90 & 07 & 23 & \\
\hline \multirow{2}{*}{$\mathrm{D}$} & 0,06 & 0,20 & 0,19 & 0,11 & 0,05 & \multirow{2}{*}{0,1266} \\
& 86 & 69 & 51 & 08 & 16 & \\
\hline \multirow{2}{*}{ Total } & 0,07 & 0,22 & 0,13 & 0,31 & 0,14 & \multirow{2}{*}{0,1783} \\
\hline
\end{tabular}

4. Berdasarkan Kriteria Sikap

Tabel 9. Bobot Prioritas Kriteria Sikap Menentukan Eigenvector

\begin{tabular}{|c|c|c|c|c|c|c|}
\hline & $\mathbf{A}$ & $\mathbf{K}$ & $\mathbf{N}$ & $\mathbf{H}$ & D & $E v$ \\
\hline & 0,09 & 0,107 & 0,07 & 0,17 & 0,093 & \\
\hline A & 44 & 5 & 67 & 04 & 5 & 0,1085 \\
\hline & 0,06 & 0,079 & 0,07 & 0,12 & 0,064 & \\
\hline $\mathrm{K}$ & 94 & 0 & 95 & 92 & 9 & 0,0844 \\
\hline & 0,46 & 0,376 & 0,37 & 0,27 & 0,410 & \\
\hline $\mathrm{N}$ & 64 & 1 & 87 & 43 & 0 & 0,3811 \\
\hline & 0,08 & 0,088 & 0,20 & 0,14 & 0,145 & \\
\hline $\mathrm{H}$ & 05 & 8 & 05 & 53 & 1 & 0,1320 \\
\hline & 0,28 & 0,348 & 0,26 & 0,28 & 0,286 & \\
\hline D & 93 & 7 & 46 & 08 & 5 & 0,2940 \\
\hline Total & & & & & & 1,0000 \\
\hline
\end{tabular}

5. Berdasarkan Kriteria Kepedulian

Tabel 7. Bobot Prioritas Kriteria Kepedulian Menentukan Eigenvector

\begin{tabular}{lllllll}
\hline & $\mathbf{A}$ & $\mathbf{K}$ & $\mathbf{N}$ & $\mathbf{H}$ & $\mathbf{D}$ & $\boldsymbol{E} \boldsymbol{v}$ \\
\hline \multirow{2}{*}{$\mathrm{A}$} & 0,08 & 0,04 & 0,16 & 0,04 & 0,086 & \multirow{2}{*}{0,0864} \\
& 74 & 67 & 69 & 45 & 6 & \\
\hline $\mathrm{K}$ & 0,15 & 0,08 & 0,07 & 0,04 & 0,109 & 0,0938 \\
\hline
\end{tabular}

\begin{tabular}{lllllll}
\hline & 49 & 27 & 92 & 25 & 5 & \\
\hline \multirow{2}{*}{$\mathrm{N}$} & 0,18 & 0,37 & 0,36 & 0,51 & 0,354 & \multirow{2}{*}{0,3610} \\
& 96 & 84 & 20 & 99 & 9 & \\
\hline \multirow{2}{*}{$\mathrm{H}$} & 0,27 & 0,27 & 0,09 & 0,14 & 0,161 & \multirow{2}{*}{0,1907} \\
& 77 & 49 & 84 & 13 & 4 & \\
\multirow{2}{*}{$\mathrm{D}$} & 0,29 & 0,21 & 0,29 & 0,25 & 0,287 & \multirow{2}{*}{0,2681} \\
& 04 & 73 & 35 & 18 & 7 & \\
\hline \multirow{2}{*}{ Total } & & & & & & 1,0000 \\
\hline
\end{tabular}

Tahap selanjutnya melakukan pengukuran konsistensi logis dengan menguji indeks konsistensi dan konsistensi rasio untuk mengetahui apakah responden memeberikan nilai dalam perbandingan antara elemen dilakukan secara konsisten, jika tidak konsisten diakibatkan karena ketidaktepatan dalam melakukan hirarki, kekurangan informasi dan keliruan dalam penulisan angka. Langkah-langkah untuk mengukur konsistensi logis sebagai berikut:

1. Mengukur Konsistensi Logis Kriteria Utama

a. Mencari Nilai Vektor [B]

Tabel 10. Vektor [B] Kriteria Utama

\begin{tabular}{lllllll}
\hline & $\mathbf{P}$ & $\mathbf{N}$ & $\mathbf{S}$ & $\mathbf{K}$ & $\boldsymbol{E} \boldsymbol{v}$ & {$[\mathbf{B}]$} \\
\hline \multirow{2}{*}{$\mathrm{P}$} & 1,000 & 4,373 & 0,284 & 0,209 & 0,157 & 4,222 \\
& 0 & 4 & 1 & 1 & 9 & 3 \\
\hline \multirow{2}{*}{$\mathrm{N}$} & 0,165 & 1,000 & 0,284 & 0,216 & 0,074 & 3,860 \\
& 7 & 0 & 1 & 5 & 4 & 6 \\
\hline \multirow{2}{*}{$\mathrm{S}$} & 3,519 & 3,519 & 1,000 & 0,488 & 0,303 & 4,438 \\
& 5 & 5 & 0 & 4 & 8 & 0 \\
\hline \multirow{2}{*}{$\mathrm{K}$} & 4,781 & 4,617 & 1,484 & 1,000 & 0,463 & 4,340 \\
& 8 & 9 & 1 & 0 & 9 & 6 \\
\hline
\end{tabular}

$\lambda \max =\frac{4,2223+3,8606+4,4380+4,3406}{4}=4,2154$

$\mathrm{CI}=\frac{4,2154-4}{3}=0,0718$

Untuk bisa menghitung CR maka harus diketahui berapa nilai Random Index (RI) yang bisa dilihat pada tabel 11 sebagi berikut:

Tabel 11. Random Index

\begin{tabular}{cc}
\hline $\mathbf{N}$ & $\mathbf{R I}$ \\
\hline 1 & 0 \\
\hline 2 & 0 \\
\hline 3 & 0,58 \\
\hline 4 & 0,9 \\
\hline 5 & 1,12 \\
\hline 6 & 1,24 \\
\hline 7 & 1,32 \\
\hline 8 & 1,41 \\
\hline 9 & 1,45 \\
\hline 10 & 1,49
\end{tabular}

Karena jumlah elemennya (n) adalah 4 maka perhitungan CR sebagai berikut:

$$
\mathrm{CR}=\frac{\mathrm{CI}}{\mathrm{RI}}=\frac{0,0718}{0,9}=0,0798
$$

Berarti CR tidak melebihi 10\% atau $<0,1$ dengan itu data tentang perbandingan berpasangan antar kriteria 
konsisten

2. Mengukur Konsistensi Logis Kriteria Penghasilan Mencari Nilai Vektor [B]

Tabel. 12. Vektor [B] Kriteria Penghasilam

\begin{tabular}{llllllll}
\hline & $\mathbf{A}$ & $\mathbf{K}$ & $\mathbf{N}$ & $\mathbf{H}$ & $\mathbf{D}$ & $\boldsymbol{E} \boldsymbol{v}$ & {$[\mathbf{B}]$} \\
\hline \multirow{2}{*}{$\mathrm{A}$} & 1,00 & 2,16 & 0,21 & 0,24 & 0,20 & 0,08 & 5,02 \\
& 00 & 89 & 87 & 22 & 16 & 17 & 58 \\
\hline \multirow{2}{*}{$\mathrm{K}$} & 0,46 & 1,00 & 0,19 & 0,36 & 0,42 & 0,06 & 5,26 \\
& 11 & 00 & 55 & 15 & 51 & 51 & 22 \\
\hline \multirow{2}{*}{$\mathrm{N}$} & 4,57 & 5,11 & 1,00 & 4,51 & 3,56 & 0,48 & 5,56 \\
& 31 & 46 & 00 & 44 & 52 & 27 & 73 \\
\hline \multirow{2}{*}{$\mathrm{H}$} & 4,12 & 2,76 & 0,22 & 1,00 & 1,24 & 0,18 & 5,57 \\
& 89 & 63 & 15 & 00 & 57 & 67 & 22 \\
\hline \multirow{2}{*}{$\mathrm{D}$} & 4,95 & 2,35 & 0,27 & 0,80 & 1,00 & 0,18 & 5,57 \\
& 93 & 22 & 46 & 27 & 00 & 37 & 84 \\
\hline
\end{tabular}

$\lambda \max =\frac{5,0258+5,2622+5,5673+5,5722+5,5784}{5}=5,4012$

$\mathrm{CI}=\frac{5,4012}{4}=0,1003$

$\mathrm{CR}=\frac{0,1003}{1,12}=0,0895$ (konsisten)

3. Mengukur Konsistensi Logis Kriteria Nilai Mencari Nilai Vektor [B]

Tabel. 13. Vektor [B] Kriteria Nilai

\begin{tabular}{llllllll}
\hline & $\mathbf{A}$ & $\mathbf{K}$ & $\mathbf{N}$ & $\mathbf{H}$ & $\mathbf{D}$ & $\boldsymbol{E} \boldsymbol{v}$ & {$[\mathbf{B}]$} \\
\hline \multirow{2}{*}{$\mathrm{A}$} & 1,00 & 2,60 & 0,28 & 2,55 & 2,40 & 0,21 & 5,63 \\
& 00 & 52 & 41 & 08 & 22 & 95 & 20 \\
\hline \multirow{2}{*}{$\mathrm{K}$} & 0,38 & 1,00 & 0,17 & 0,29 & 0,27 & 0,05 & 5,33 \\
& 39 & 00 & 48 & 47 & 17 & 61 & 42 \\
\hline \multirow{2}{*}{$\mathrm{N}$} & 3,51 & 5,72 & 1,00 & 2,35 & 2,82 & 0,41 & 5,51 \\
& 95 & 03 & 00 & 22 & 52 & 94 & 95 \\
\hline \multirow{2}{*}{$\mathrm{H}$} & 0,39 & 3,39 & 0,42 & 1,00 & 0,35 & 0,12 & 5,09 \\
& 20 & 35 & 51 & 00 & 40 & 66 & 05 \\
\hline \multirow{2}{*}{$\mathrm{D}$} & 0,41 & 3,68 & 0,29 & 2,82 & 1,00 & 0,17 & 5,37 \\
& 63 & 01 & 47 & 52 & 00 & 83 & 07 \\
\hline
\end{tabular}

$\lambda \max =\frac{5,6320+5,3342+5,5195+5,0905+5,3707}{5}=5,3894$

$\mathrm{CI}=\frac{5,3894-5}{4}=0,0973$

$\mathrm{CR}=\frac{0,0827}{1,12}=0,0869$ (konsisten)

4. Mengukur Konsistensi Logis Sikap Mencari Nilai Vektor [B]

Tabel. 14. Vektor [B] Kriteria Sikap

\begin{tabular}{llllllll}
\hline & $\mathbf{A}$ & $\mathbf{K}$ & $\mathbf{N}$ & $\mathbf{H}$ & $\mathbf{D}$ & $\boldsymbol{E v}$ & {$[\mathbf{B}]$} \\
\hline & 1,00 & 1,36 & 0,20 & 1,17 & 0,32 & 0,10 & 5,08 \\
$\mathrm{~A}$ & 00 & 08 & 25 & 32 & 64 & 85 & 17 \\
\hline & 0,73 & 1,00 & 0,21 & 0,88 & 0,22 & 0,08 & 5,07 \\
$\mathrm{~K}$ & 48 & 00 & 00 & 91 & 64 & 44 & 35 \\
\hline & 4,93 & 4,76 & 1,00 & 1,88 & 1,43 & 0,38 & 5,21 \\
$\mathrm{~N}$ & 93 & 25 & 00 & 82 & 10 & 11 & 90 \\
\hline
\end{tabular}

\begin{tabular}{llllllll}
\hline & 0,85 & 1,12 & 0,52 & 1,00 & 0,50 & 0,13 & 5,07 \\
$\mathrm{H}$ & 24 & 47 & 96 & 00 & 65 & 20 & 52 \\
\hline & 3,06 & 4,41 & 0,69 & 1,93 & 1,00 & 0,29 & 5,17 \\
$\mathrm{D}$ & 39 & 63 & 88 & 32 & 00 & 40 & 23 \\
\hline
\end{tabular}

$\lambda \max =\frac{5,0817+5,0735+5,2190+5,0752+5,1723}{5}=5,1243$

$\mathrm{CI}=\frac{5,1243-5}{4}=0,0311$

$\mathrm{CR}=\frac{0,0311}{1,12}=0,0278$ (konsisten)

5. Mengukur konsistensi logis kepedulian Mencari nilai vektor [B]

Tabel. 15. Vektor [B] Kriteria Kepedulian

\begin{tabular}{llllllll}
\hline & $\mathbf{A}$ & $\mathbf{K}$ & $\mathbf{N}$ & $\mathbf{H}$ & $\mathbf{D}$ & $\boldsymbol{E} \boldsymbol{v}$ & {$[\mathbf{B}]$} \\
\hline \multirow{2}{*}{$\mathrm{A}$} & 1,00 & 0,56 & 0,46 & 0,31 & 0,30 & 0,08 & 5,16 \\
& 00 & 41 & 11 & 47 & 10 & 64 & 68 \\
\hline \multirow{2}{*}{$\mathrm{K}$} & 1,77 & 1,00 & 0,21 & 0,30 & 0,38 & 0,09 & 5,17 \\
& 26 & 00 & 87 & 10 & 07 & 38 & 58 \\
$\mathrm{~N}$ & 2,16 & 4,57 & 1,00 & 3,68 & 1,23 & 0,36 & 5,56 \\
& 89 & 31 & 00 & 01 & 36 & 10 & 83 \\
\hline \multirow{2}{*}{$\mathrm{H}$} & 3,17 & 3,32 & 0,27 & 1,00 & 0,56 & 0,19 & 5,37 \\
& 77 & 27 & 17 & 00 & 10 & 07 & 60 \\
\hline \multirow{2}{*}{$\mathrm{D}$} & 3,32 & 2,62 & 0,81 & 1,78 & 1,00 & 0,26 & 5,34 \\
& 27 & 65 & 06 & 26 & 00 & 81 & 85 \\
\hline
\end{tabular}

$\lambda \max =\frac{5,1668+5,1758+5,5683+5,3760+5,3485}{5}=5,3271$

$\mathrm{CI}=\frac{5,3271-5}{4}=0,0818$

$\mathrm{CR}=\frac{0,0818}{1,12}=0,0730$ (konsisten $)$

Tahap selanjutnya membuat prioritas global dengan cara bobot prioritas setiap altenatif dikalikan dengan bobot prioritas kriteria:

$$
\begin{gathered}
\left(\begin{array}{llll}
0,081 & 0,2195 & 0,1085 & 0,0864 \\
0,0651 & 0,0561 & 0,0844 & 0,0938 \\
0,4827 & 0,4194 & 0,3811 & 0,3610 \\
0,1867 & 0,1266 & 0,1320 & 0,1907 \\
0,1837 & 0,1783 & 0,2940 & 0,2681
\end{array}\right) \times\left(\begin{array}{l}
0,1579 \\
0,0744 \\
0,3038 \\
0,4639
\end{array}\right) \\
=\left(\begin{array}{l}
0,1023 \\
0,0836 \\
0,3906 \\
0,1675 \\
0,2560
\end{array}\right)
\end{gathered}
$$

Berdasarkan perhitungan prioritas global pada penelitian ini, diperoleh nilai Ahmad 0,1023, Keyza memperoleh nilai 0,0836, Nazwa memperoleh 0,3906, Haikal memperoleh 0,1675 dan Daniar memperoleh 0,2560. Nilai akhir tersebut yang digunakan sebagai dasar untuk menentukan yang layak mendapatkan beasiswa pada program beasiswa pelangi penghimpunan INTI, sehingga menghasilkan keputusan 3 pemohon yang mendapatka beasiswa di peroleh Nazwa, Daniar dan Haikal. 


\section{B. Rancangan Prototype Penerima Beasiswa Metode AHP}

Rancangan prototype untuk menentukan penerimaan beasiswa INTI Pelangi menggunakan metode pengembangan prototype. Prototyping merupakan metode pengembangan perangkat lunak dengan spesifikasi kebutuhan yang diinginkan pelanggan dalam gambaran dasar suatu program dan melakukan pengujian awal. prototyping.memberikan peluang bagi pengembang dan pengguna selama proses pembuatan untuk saling berinteraksi, sehingga pengembang dengan mudah memodelkan perangkat lunak yang akan dibuat [11]. Langkah-langkah dalam tahapan metode pengembangan perangkat lunak Menurut Ogedebe , prototyping dimulai dengan pengumpulan kebutuhan, melibatkan pengembang dan pengguna sistem untuk menentukan tujuan, fungsi dan kebutuhan operasional sistem. Langkah-langkah dalam prototyping adalah sebagai berikut [11] :

a. Pengumpulan Kebutuhan.

b. Proses desain yang cepat.

c. Membangun prototipe.

d. Evaluasi dan perbaikan.

Setelah langkah dalam prototyping telah dilakukan maka langkah selanjutnya pembuatan produk yang sesungguhnya.

Rancangan prototype pada penerimaan beasiswa INTI Pelangi menggunakan metode pengembangan prototype sebagai berikut:

1. Tampilan login

User untuk bisa melakukan penyeleksi beasiswa maka user melakukan login terlebih dahulu. Untuk bisa login user harus menginput email dan password, yang bisa dilihat pada gambar 2. Sebagai berikut:

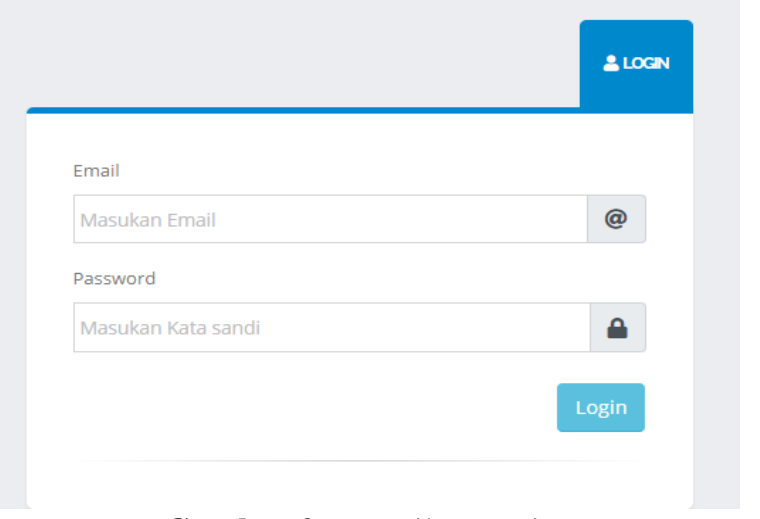

Gambar 2. Tampilan Login

2. Halaman Siswa

Halaman siswa yang merupakan input data siswa yang dapat dilihat pada gambar 3 sebagai berikut:

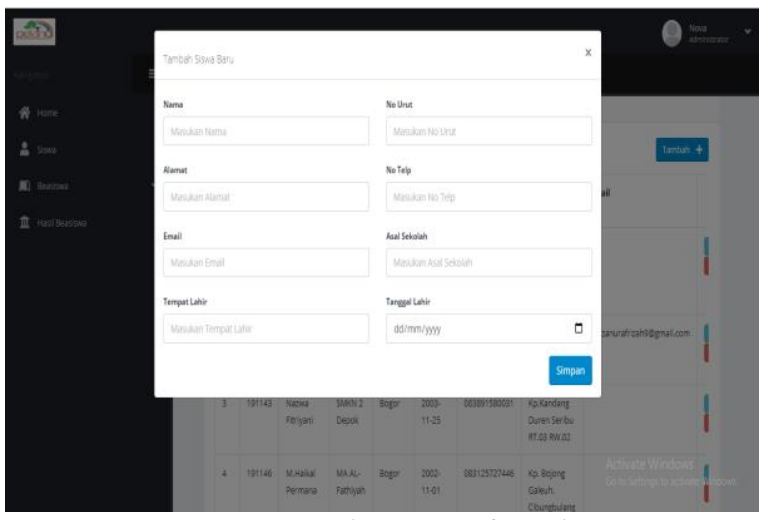

Gambar 3. Halaman Daftar Siswa

3. Halaman Daftar Siswa

Halaman daftar siswa merupakan daftar nama-nama siswa yang sudah di input pada halaman siswa, pada halaman daftar siswa bisa mengedit dan menghapus data siswa. Pada halaman daftar siswa dapat dilihat pada gambar 4 sebagai berikut:

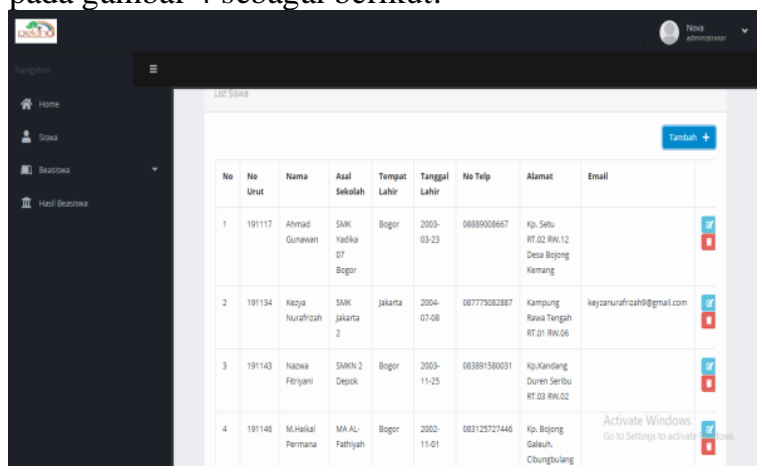

Gambar 4. Halaman Data Siswa

4. Halaman Kriteria

Halaman kriteria berguna untuk menilai perbandingan seberapa penting antara kriteria yang satu dengan yang lain. halaman kriteria dapat dilihat pada gambar 5 sebagai berikut:

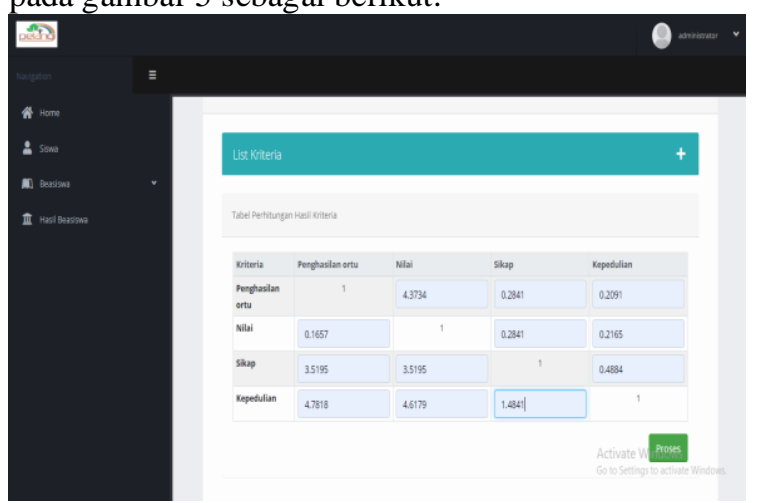

Gambar 5. Halaman Kriteria

5. Tampilan Konsistensi Logis

Tampilan konsistensi logis merupakan hasil perhitungan dari penilaian kriteria pada halaman kriteria. Hasil perhitungan yang ada ditampilan konsistensi logis terfiri dari bobot prioritas, nilai 
lamda max, CI dan CR yang dapat dilihat pada gambar 6 sebagai berikut:

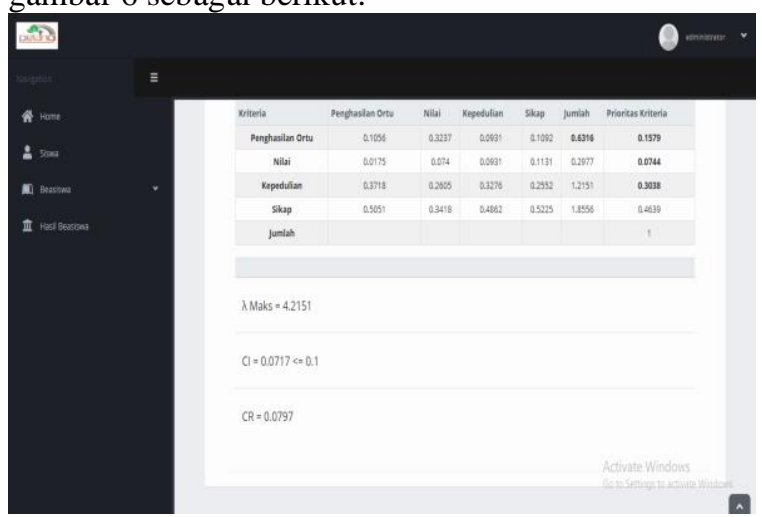

Gambar 6. Tampilan Konsistensi Logis

6. Halaman Altenatif

Halaman altenatif merupakan halaman untuk menilai siswa yang ingin diberikan penilaian, user harus memilih siapa saja siswa yang ingin diberikan penilaian pada saat wawancara seleksi beasiswa terhadap siswa dilakukan. Halaman altenatif dapat dilihat pada gambar 7 sebagai berikut:

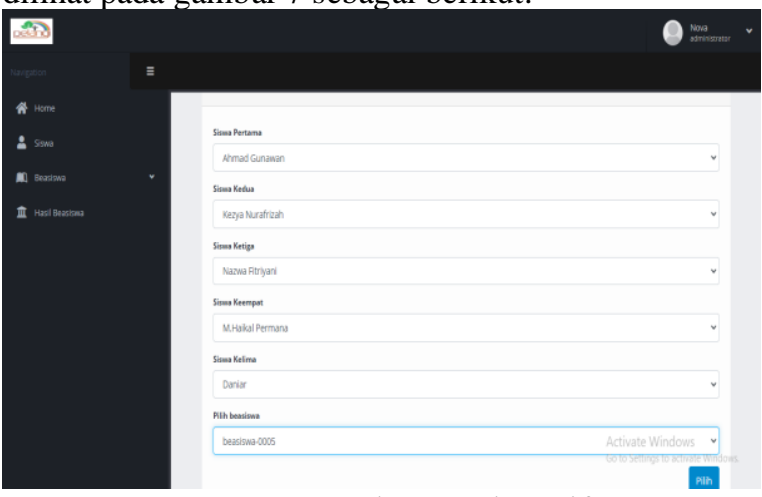

Gambar 7. Halaman Altenatif

7. Halaman Penilaian Altenatif

Ketika user sudah memilih siswa yang ingin diberikan penilaian maka user dapat melakukan penilaian terhadap altenatif yang berkaitan dengan kriteria. Halaman penilaian altenatif dapat dilihat pada gambar 8 sebagai berikut:

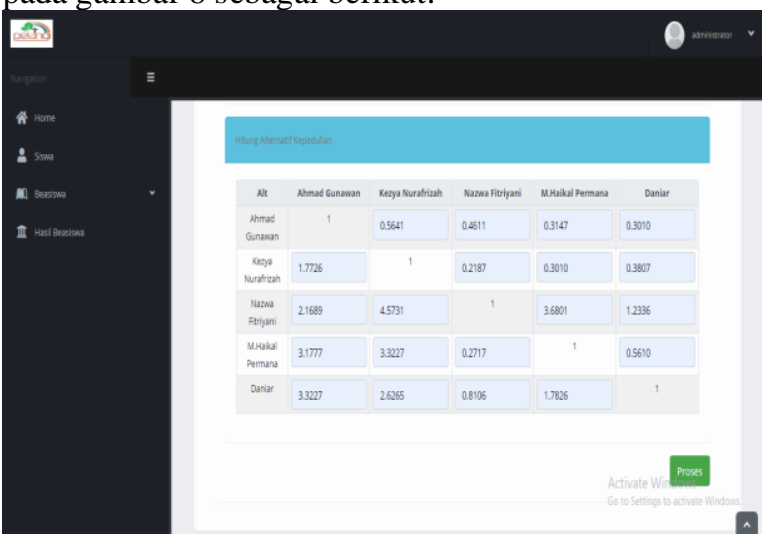

Gambar 8. Halaman Penilaian Altenatif
Setelah altenatif atau siswa sudah diberikan penilaian maka akan terlihat bobot prioritas dan hasil prioritas global dari penilaian altenatif terkaitannya dengan kriteria yang dapat dilihat pada gambar 9 sebagai berikut:

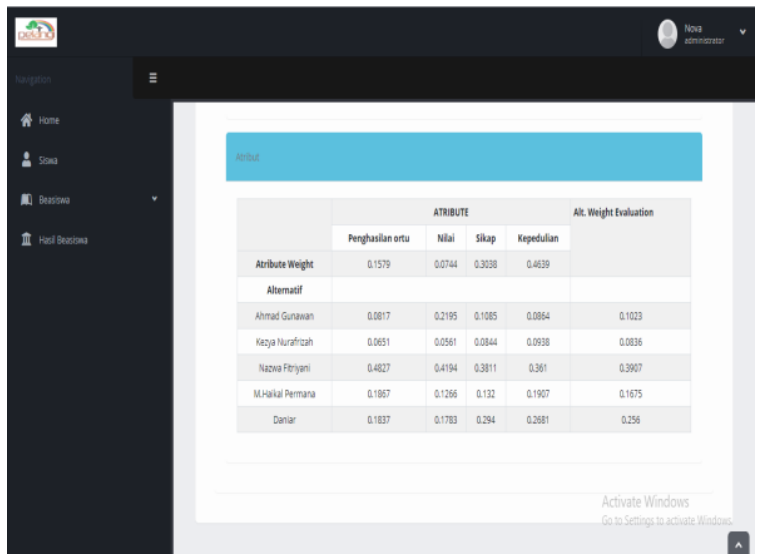

Gambar 9. Halaman Hasil Prioritas Global

\section{Hasil Beasiswa}

Dari hasil prioritas global maka dapat diperoleh perengkingan dan hasil seleksi yang lulus dan yang tidak lulus, yang dapat dilihat pada gambar 10 sebagai berikut:

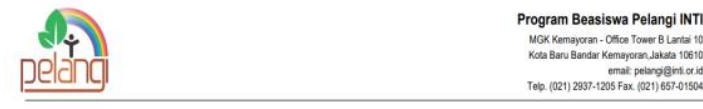

Hasil Beasiswa

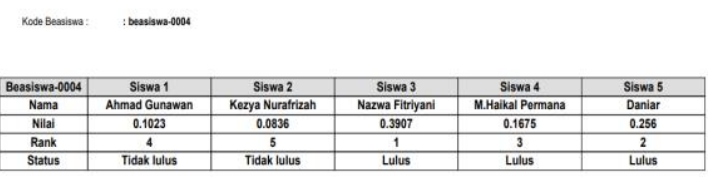

Gambar 10. Halaman Beaiswa

\section{Kesimpulan}

Berdasarkan perhitungan manual menggunakan metode Analytical Hierarchy Process, diperoleh prioritas kriteria kepedulian sosial yang paling penting dan selanjutnya sikap, penghasilan orang tua dan terakhir nilai untuk menentukan beasiswa pada program beasiswa pelangi penghimpunan INTI. Dalam perhitungan manual penerimaan beasiswa menggunakan metode Analytical Hierarchy Process yang diperoleh dari hasil penilaian 5 responden, maka dapat memberikan keputusan bahwa Nazwa yang memiliki nilai tertinggi dan berhak mendapatkan beasiswa dengan memperoleh nilai 0,3906 selanjutnya Daniar dengan nilai 0,2560 dan haikal memperoleh nilai 0,1675 . Ahmad dengan memperoleh nilai 0,1023 dan Keyza dengan nilai 0,0836 dengan mendapatkan nilai yang rendah maka ahmad dan keyza tidak lolos mendapatkan beasiswa.

\section{Daftar Pustaka}

8. Halaman Hasil Prioritas Global 
[1] Helaluddin, "Restrukturisasi Pendidikan Berbasis Budaya: Penerapan Teori Esensialisme Di Indonesia," J. Dimens. Pendidik. dan Pembelajaran, vol. 6, no. 2, pp. 74-82, 2018.

[2] M. Silviliyana, I. Maylasari, R. Agustina, F. R. Dewi, and N. P. Sulistyowati, Potret Pendidikan Indonesia Statistik Pendidikan 2019. Jakarta: Badan Pusat Statistik, Jakarta-Indonesia, 2019.

[3] Y. Rachmawati, I. Maylasari, R. Sulistyowati, M. Silviliyana, L. Annisa, and F. W. R. Dewi, Potret Pendidikan Indonesia Statistik Pendidikan 2018. Jakarta, 2018.

[4] R. Ramadhon, R. Jaenudin, and S. Fatimah, "Pengaruh Beasiswa Terhadap Motivasi Belajar Mahasiswa Pendidikan Ekonomi Universitas Sriwijaya," J. PROFIT, vol. 4, no. 2, pp. 203213, 2017.

[5] D. Sulistyo and S. Winiarti, "Penentuan Beasiswa Siswa Kurang Mampu," J. Inform., vol. 9, no. 1, pp. 965-974, 2015.

[6] D. P. Sari, "Penerapan Metode Saw (Simple Additive Weighting) Dalam Sistem Pendukung Keputusan Untuk Menentukan Penerima Beasiswa Pada Smk N 2 Payakumbuh," J. JClick J. Sist. Inf. dan Manaj. Inform., vol. 5, no. 2, pp. 207-216, 2018.
[7] S. Syam, "Sistem Pendukung Keputusan Potensi Siswa Dengan Metode Fuzzy Multiple-Attribute Decision Making ( FMADM ) ( Studi Kasus: Pada SDN Maccini 1 Makassar )," J. Keilmuan dan Adplikasi Tek., vol. 5, no. 2, pp. 30-36, 2018.

[8] Marsono, Penggunaan Metode Analytical Hierarchy Process (AHP) dalam Penelitian. Bogor: In Media, 2020.

[9] N. P. N. Hendayanti and I. K. P. Suniantara, "Seleksi Penerimaan Beasiswa Stikom Bali Dengan Menggunakan Metode Vikor," Statistika, vol. 5, no. 1, pp. 46-51, 2017.

[10] U. Rahmalisa and Muhardi, "Penerapan Metode TOPSIS untuk Seleksi Penerima Beasiswa ( Studi Kasus: SMAN 2 Tebing Tinggi Timur )," J. Teknol. Sist. Inf. dan Apl., vol. 2, no. 1, pp. 3135, 2019.

[11] W. W. Widiyanto, “Analisa Metodologi Pengembangan Sistem Dengan Perbandingan Model Perangkat Lunak Sistem Informasi Kepegawaian Menggunakan Waterfall Development Model, Model Prototype, Dan Model Rapid Application Development (RAD)," J. Inf. Politek. Indonusa Surakarta, vol. 4, no. 1, pp. 34-40, 2018. 